\title{
EMPLOYEE BENEFITS IN MULTINATIONAL FIRMS: EMPIRICAL EVIDENCE FOR ROMANIA AND SERBIA
}

\begin{abstract}
The paper aims to analyse post-employment benefits provided by multinational firms, focusing on retirement advantages and pension systems in Romania and Serbia from a comparative empirical perspective. Economic literature highlights the essential role played by pension schemes in assuring a proper level of income after retirement, thus reducing poverty and increasing productivity, with significant positive implications upon overall economic activity. Our research is based on developing several double-log fixed and random effects models, as well as a dynamic and distributed lags model, using a panel structure over the 20052013 period and a complex set of indicators (national accounts - GDP total and per capita; labour market - employment, unemployment, productivity, earnings; secondary and tertiary education; pension specific data - general beneficiaries, old age and survivor pensioners, total and by gender, and pension expenses as percentage of GDP). The results show that pensions represent an incentive for employees leading to an increase in resource productivity. At the same time, old age pensions are positively shaping economic growth and employment for the two countries considered, significantly reducing the poverty rate for pensioners. Nevertheless, the two pensions systems are modelled by the economic activity, educational background of employees, as well as by the level of net earnings.
\end{abstract}

Key words: Employee benefits, Economic growth, Earnings, Pension system, Productivity

\section{Introduction}

Employee benefits represent a complex set of incentives granted by employers (companies and various entities) in order to acquire and maintain their workers and to increase security and labor productivity within the framework of a spe-

\footnotetext{
Margareta Caran, PhD Student, Faculty of Economics and Business Administration, West University of Timisoara, Romania, e-mail: margareta.maggie@yahoo.com

** Gratiela Georgiana Noja, PhD Lecturer, Faculty of Economics and Business

Administration, West University of Timisoara, Romania, e-mail: gratiela.noja@e-uvt.ro
} 
cific job ${ }^{1}$. During the last few years, the budgets allocated for employees (human resources) have significantly decreased within the unfavorable economic context shaped by the global economic and financial crisis. Thus, employers transfer the costs of employee accounting and the entire process of adopting these types of decisions towards their workers. This procedure determined entities to become more creative in their efforts to stay competitive in hiring and maintaining their employees. Moreover, employers continue to shape their employee benefits schemes, by insuring a higher responsibility to workers for their coordination.

Overall, according to the 2012 report of the Society for Human Resource Management, the pre-defined pension plans based on employee contributions represent one of the most common and important post-employment advantages granted by firms (92\%), followed by saving schemes (34\%) or traditional pension plans (21\%). In the case of pre-defined pension plans, the employer states that he will contribute with a certain fixed amount or even that he won't contribute at all to the individual account of the employee. Thus, the employee takes the risk of investing in these pension schemes since the values of performed investment through the pension account can decrease with time. Within this context, globally there are about $68 \%$ of the companies ensuring a similar scheme for all or even just for certain employee contributions and $66 \%$ of the companies granted loans for pre-defined pension plans based on contributions. These types of loans allow participants to borrow from the pension savings through specific types of developed schemes. Moreover, 39\% of the companies have automatically subscribed their workers in pre-defined pension schemes, except for the case when they specifically mentioned that don't want to be caught in these types of systems.

Pre-defined benefits pension plans differ from pension schemes based on contributions through the fact that the employer promises to pay a certain benefit until worker's retirement, the amount granted being established according to specific factors such as age, earnings or working hours. Nevertheless, employers take the investment risk because they will have to pay the promise amount independently from the performance of investment plan. Globally, a relatively low share of companies (about 12\%) have reported a temporary blockage of these pension schemes in 2012, thus making them unavailable for new employees.

Banerjee Dina, Perrucci Cummings Carolyn (2012): "Employee Benefits and Policies: Do They Make a Difference for Work/Family Conflict?”, Journal of Sociology \& Social Welfare, 39(3). 
Table 1: Types of employee benefits granted to workers under the form of pension plans and schemes by various companies globally, 2008-2012

\begin{tabular}{|l|c|c|c|c|c|}
\hline Retirement (pension) benefits & \multicolumn{5}{|c|}{$\%$ of companies offering employee } \\
& \multicolumn{3}{|c|}{ benefits globally } \\
\hline & 2008 & 2009 & 2010 & 2011 & 2012 \\
\hline Pre-defined contribution pension plans & $84 \%$ & $90 \%$ & $92 \%$ & $93 \%$ & $92 \%$ \\
\hline $\begin{array}{l}\text { Similar pension schemes of employers for pre-defined } \\
\text { contribution pension plans of employees }\end{array}$ & $75 \%$ & $72 \%$ & $72 \%$ & $70 \%$ & $68 \%$ \\
\hline Loans granted based on pre-defined contribution pension plans & $69 \%$ & $69 \%$ & $69 \%$ & $69 \%$ & $66 \%$ \\
\hline On-line investment consultancy & - & - & - & - & $55 \%$ \\
\hline Personal investment consultancy & $40 \%$ & $38 \%$ & $40 \%$ & $42 \%$ & $44 \%$ \\
\hline Group investment advices and consultancy & - & - & - & - & $41 \%$ \\
\hline Automated subscribing for pre-defined contribution pension plans & $32 \%$ & $35 \%$ & $39 \%$ & $41 \%$ & $39 \%$ \\
\hline Planning advices and preparing for retirement & $38 \%$ & $35 \%$ & $39 \%$ & $37 \%$ & $39 \%$ \\
\hline Pension plans available for all employees & $33 \%$ & $29 \%$ & $27 \%$ & $22 \%$ & $21 \%$ \\
\hline Equilibrated pension plans granted in cash & $9 \%$ & $6 \%$ & $9 \%$ & $8 \%$ & $6 \%$ \\
\hline Formally defined pension plans & $6 \%$ & $6 \%$ & $6 \%$ & $5 \%$ & $5 \%$ \\
\hline Informally defined pension plans & - & - & - & - & $5 \%$ \\
\hline Pre-defined contribution pension plans based on debit cards & - & $1 \%$ & $2 \%$ & $1 \%$ & $2 \%$ \\
\hline
\end{tabular}

Source: Society for Human Resource Management (SHRM), 2012 Employee benefits: A Research Report, The Employee Benefits Landscape in a Recovering Economy.

Taking into account all these aspects, the research performed within this paper has a double objective: (i) first, the identification and highlight of postemployment benefits focusing on retirement, respectively on the existing pension plans and schemes in Romania and Serbia and the specific labor market mechanisms related to pension incentives and their linkages to labor productivity; (ii) second, performing an empirical analysis in order to identify and assess pension systems shaping factors for the two countries considered, as well as the impact of pension plans on economic activity and growth, long term economic development, labor market stability, productivity and earnings.

\section{Literature review on employee benefits}

The International Accounting Standard - IAS 19 describes the main types of employee benefits, including: (i) short-term benefits, such as wages, weekly rewards and social security contributions, paid annual and sick leave, bonuses, profit participation, as well as other non-monetary advantages, such as medi- 
cal care, cars or other free goods and services provided by entities; (ii) postemployment benefits: pensions, other retirement advantages or post-employment medical assistance; (iii) other long-term benefits, including long-service leave and other long-service advantages, disability benefits, bonuses, profit-sharing and deferred compensation; (iv) termination benefits.

\section{Post-employment benefits in the economic literature}

The labor market and pension analysis within the new institutional economy perspective $^{2}$ highlights the importance of modeling the labor market policies and practices through effective and efficient solutions of productivity increase, generated by asymmetric or incomplete information. Economists applied this approach on employment factors and wages, such as labor earnings, inter-industrial wage differentials, bonuses and incentives for anticipated early retirement. ${ }^{3}$

Pensions represent one of the most important labor market institutions, assuring a high and increasing percentage of income for pensioners. The internal perspective on labor markets highlights that pensions generate incentives which promote labor productivity, along with insuring the necessary means for saving during the pension period. Employees involved into a pension scheme are maximizing their welfare in retirement by working without interruption during their entire lifetime until they reach the retirement age. ${ }^{4}$ The pension income is a result of the four specific pillars supporting elderly people, such as redistributive public pensions (pay as you go), private pensions with fund accumulation, private direct savings and post-retirement work. ${ }^{5}$

Economic theories on retirement reveal that the process of granting pensions by the government after retirement has a negative impact on savings during their active labor market participation and lifetime. Therefore, public and private pension plans are the main essential sources to provide the necessary income for the retirement period. In this context, the main indicators used to analyze the performance of various pension plans/ schemes are generally the dependency rate, respectively the fraction between the total number of pensioners and total active population, as well as the output and efficiency of assets accumulated in pension funds or labor productivity.

Taking into consideration all these aspects, we can highlight that globally there are two main types of pension schemes, respectively: (i) the pay as you go

2 Simon Herbert (1991): “Organizations and Markets", Journal of Economic Perspectives, American Economic Association, 5(2).

3 Dorsey Stuart, Cornwell Christopher, Macpherson David (1998): "Pensions and the Labor Market", in Pensions and Productivity, Kalamazoo, MI: W.E. Upjohn Institute for Employment Research, 2.

4 Clark Robert, Morrill Melinda Sandler, Vanderweide David (2013): "Defined benefit pension plan distribution decisions by public sector employees", Journal of Public Economics.

5 Beju D. (2007): "Coordonate ale reformei sistemului de pensii: cazul României", Transylvanian Review of Administrative Sciences, 17. 
pension system, based on long term savings and resource transfer from young to elderly people and (ii) accumulating funds pension system, which is also a long term saving program, but it implies resource transfer from youth to seniority.

Economic theories on pensions generally conduct the hypothesis that pension schemes increase labor productivity. This offer perspective follows the economists' assumption that pension incentives should generate sufficient added value in order to cover the costs. The constraints applied upon workers' ability to get more attractive jobs or to retire when they desire are extremely expensive, requiring that employers should pay compensation wages in order to attract employees. Employers can also attract workers at a lower cost by offering pension contributions if within those firms the pension incentives don't have productive functions.

In a different perspective outside the economic literature, the possibility for pension to be an instrument that promotes productivity is intentionally ignored or eliminated from the research and debates on pensions and retirement policies. The human resources approach observes pensions as being almost totally coordinated by the preferences of employees. Thus, the imperfect portability of advantages was mainly presented as a disadvantage of pre-defined benefit schemes, rather than a voluntary compensation policy. Nevertheless, pensions are usually discussed within the context of employee benefits, focusing on insuring them the retirement security. This perspective presents pensions exclusively as a mean to insure the necessary income for the after-retirement period.

At the same time, Lazear $(1990)^{6}$ concluded that managers view pensions under the form of saving instruments for the after-retirement period, suggesting that they fail to understand the implications of pension incentives on output/ labor productivity, respectively the way in which these might have a strategic value. The economic literature points out the utility of pension incentives and instruments for companies and employees. Still, economists often characterize the penalties given for dropping the pension as barriers to an efficient mobility between jobs. ${ }^{7}$ Nevertheless, Mulvaney $(2011)^{8}$ describes two major arguments for legal reinforcement of pension portability: (i) first, a high portability could increase pension benefits for those workers which, for various reasons, have experienced frequent job changes; (ii) second, the non-portability reduces labor productivity because it links workers to their job where productivity decreased due to various changes in consumer behavior and preferences or technological shocks.

Lazear Edward (2000): "Performance Pay and Productivity", American Economic Review, American Economic Association, 90(5).

Dorsey et al., 5.

8 Mulvaney Michael (2011): „A Study of the Role of Family-Friendly Employee Benefits Programs, Job Attitudes, and Self-Efficacy among Public Park and Recreation Employees", Journal of Park and Recreation Administration, 29(1). 


\section{Employee benefits as pensions in Romania and Serbia: a comparative analysis}

The Romanian and Serbian socio-economic and demographic context during the last decade reveals the importance of pension systems and social security benefits that can ensure the necessary income for the after-retirement period, as well as significant employee advantages legally reinforced.

In Romania, according to official data provided by the National House of Public Pensions, in December 2014 there were 4692711 pensioners, of which 3360361 were old-age pension beneficiaries, 21062 had an anticipated pension, 91089 had a partial anticipated pension, 686619 were disability pension beneficiaries and 532943 were survivor pensioners. At the same time, 637 people received social help of which $70 \%$ were females and 3675 people were comprised in a special category of invalidity and war widower's pension. Moreover, compared to the same period of previous year, there is a slight increase in pension values for Romania, especially in the case of old-age and anticipated pensions, while the disability and survivor pensions have increased at a much lower rate.

If we take into consideration the district distribution of the number of pensioners in Romania during 2013, we can observe that the districts with the highest number of pensioners are Timiș, Bihor, Cluj, Dolj, Argeş, Braşov, Prahova, Iaşi, Bacău and Bucharest, while a smaller number of pension beneficiaries are registered in Mehedinți, Sălaj, Bistrița-Năsăud, Harghita, Covasna, Giurgiu and Călăraşi. At the end of 2014, the geographical distribution of the number of pensioners in Romania is almost similar to the one registered in the previous year, with small changes for two districts, respectively Botoșani and Caraș-Severin.

Figure 1: Distribution by districts of the number of pensioners, total social security contributions in Romania
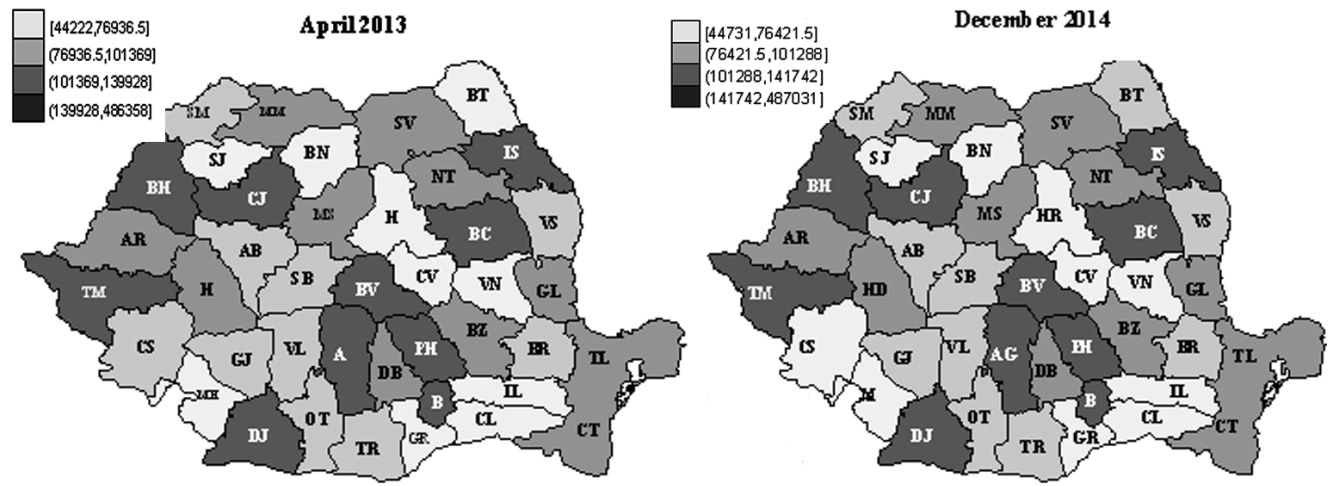

Source: own process of statistical data published by the National House of Public Pensions in Stata 11 
In 2014 the pension value remained unchanged compared to the previous year in almost all Romanian administrative counties, except for Bihor county where the average pension value overall social security registered a slight decrease.

Figure 2: Average pension overall social security contributions by Romanian administrative counties

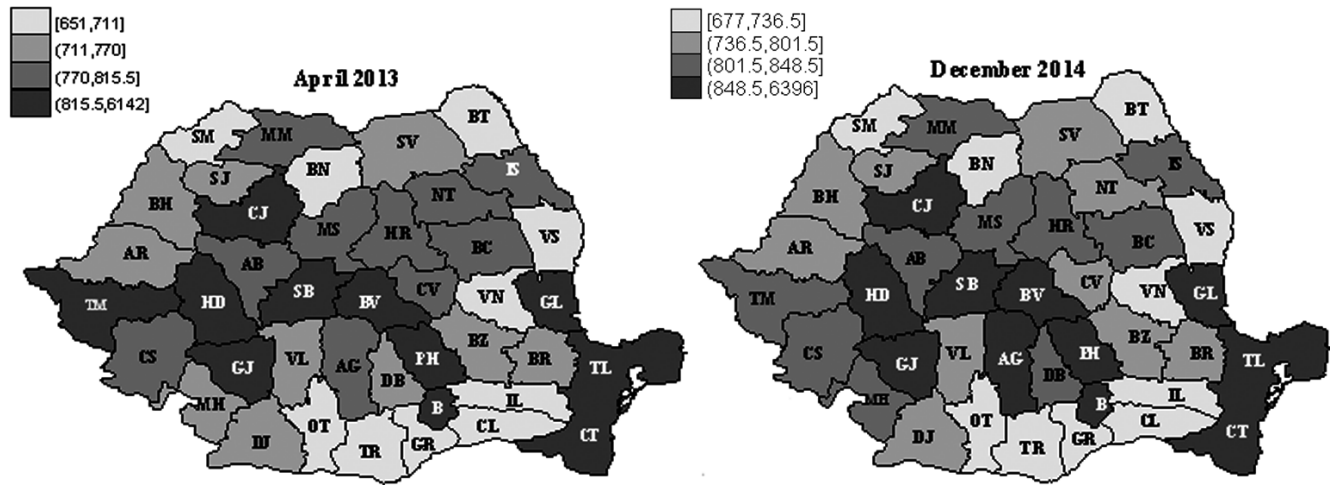

Source: own process of statistical data published by the National House of Public Pensions in Stata 11

The analysis performed based on pension indicators for Serbia during 20052013 highlights that there are three major types of pensions granted, respectively old-age, disability (invalidity) and survivor pensions. In 2013, Serbia registered a total number of about 1.74 million pension beneficiaries, most of which were women (about 970000). During 2005-2013 the evolution of pension beneficiaries was relatively stable, with an increasing trend especially in the second part of the period, respectively 2012 and 2013.

In the case of old-age pension beneficiaries, during 2005-2013 the number of pensioners has significantly increased, from about from about 950000 to 1.22 million people, most of them being males. In 2010, from the total number of pensioners in Serbia, more than half were old-age pensioners (55.3\%), while $22.6 \%$ of the total pension beneficiaries have had disability pensions and $22.1 \%$ of the total pensions granted were survivor pensions. 
Figure 3: Pension beneficiaries in Serbia, 2005-2013, total types of pensions and according to gender (right), respectively the employment density (employees by $\mathrm{km} 2$ ) in 2013 (left)
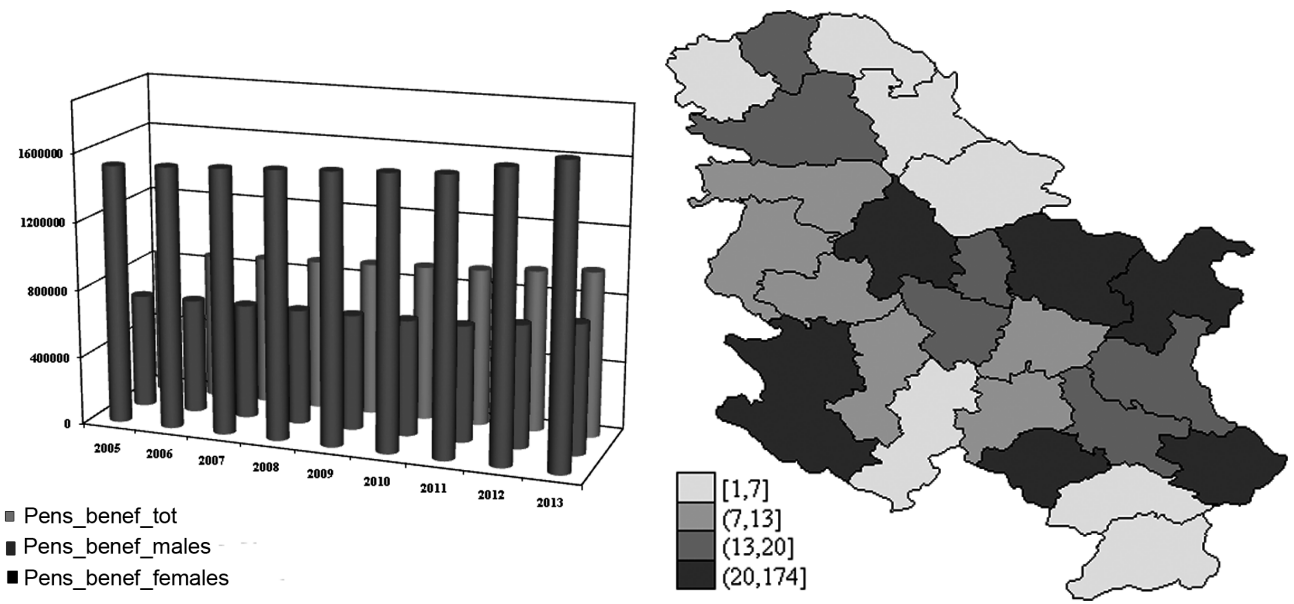

Source: own process of data published by the Statistical Office of the Republic of Serbia

Within this framework, we can state that, even though during the last few years the percentage of old-age pension beneficiaries has increased significantly, still, it remains at a low unfavorable level. The context is even more unstable in the case of employees as major type of insurance, where the percentage of old-age pensioners has reached $50 \%$ only in 2008 . Nevertheless, the number of pensioners with disability pension registered a decline during 2005-2013, both in absolute and relative terms.

4. Methodology and data: developed models, ecuations, limits and testing

\subsection{General form of developed models}

The model developed for the analysis of pension systems determinants and shaping factors has the general form of a multiple regression model with panel data. Thus, for panel data, the general linear representation of the model is described as follows ${ }^{9}$ :

$$
\begin{aligned}
& y_{i t}=\sum_{k=1}^{k} x_{k i t} \beta_{k i t}+\varepsilon_{i t} \\
& i=1, \ldots, N \\
& t=1, \ldots, T
\end{aligned}
$$

Baum F. Christopher (2001): An Introduction to Modern Econometrics Using Stata, Stata Press, 219. 
where: $N$ represents the number of panel units (countries), while $T$ signifies the number of periods (time).

The fixed effects model has the following representation ${ }^{10}$ :

$$
y_{i t}=x_{i t} \beta_{k}+z_{i} \delta+u_{i}+\varepsilon_{i t}
$$

where $x_{i t}$ is a $1 x k$ vector of variables varying between countries and in time, $\beta$ represents a $1 \times k$ vector of $x$ coefficients, $z_{i}$ is a $1 \times p$ vector of the variables that are constant in time, but vary between countries (as elements of the panel), $\delta$ represents a $p x 1$ vector of $z$ coefficients, $u_{i}$ is the individual effects, for every element of the panel, and $\varepsilon_{i t}$ is the disturbance term.

The random effects model has the following representation ${ }^{11}$ :

$$
y_{i t}=x_{i t} \beta+z_{i} \delta+\left(u_{i}+\varepsilon_{i t}\right)
$$

where: $u_{i}+\varepsilon_{i}$ represents the compouned disturbance term, and $u_{i}$ reflects the indi- ${ }^{u_{i}+\varepsilon_{i}}$ vidual effects.

The general form of the developed model comprises several explanatory variables used within the analysis of the pension systems shaping factors and economic impact for considered panel countries:

$$
Y_{i t}=\beta_{1} X_{1 i t}+\beta_{2} X_{2 i t}+\beta_{3} X_{3 i t}+\ldots+\beta_{k} X_{k i t}+\varepsilon_{t i}, i=1, \ldots, n
$$

The proposed model uses the logarithm of the variables in order to capture a precise estimation of parameters, respectively of the influence of different variables on the emigration process, thus taking the general form of a double-log model, with the following configuration:

$$
\log \left(Y_{i t}\right)=\beta_{1} \log \left(X_{1 i t}\right)+\beta_{2} \log \left(X_{2 i t}\right)+\beta_{3} \log \left(X_{3 i t}\right)+\ldots+\beta_{k} \log \left(X_{k i t}\right)+\varepsilon_{i t}, i=1, \ldots, n
$$

The model's general equation can be rewritten under the following form taking into consideration the shaping factors of pension systems:

$$
\begin{aligned}
& P B T_{i t}=\beta_{0}+\beta_{1} \text { GDPtot }_{i t}+\beta_{2} U R_{i t}+\beta_{3} N E_{i t}+\beta_{4} \text { EDtert }_{i t}+\varepsilon_{i t} \\
& P B T_{i t}=\beta_{0}+\beta_{1} \text { GDPcap }_{i t}+\beta_{2} U R_{i t}+\beta_{3} N E_{i t}+\beta_{4} \text { EDtert }_{i t}+\varepsilon_{i t}
\end{aligned}
$$

where:

$\mathrm{PBT}=$ Pension Beneficiaries, total types of pensions; this pension specific indicator is used alternatively with the number of old-age pensioners (PBOA),

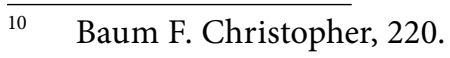

11 Baum F. Christopher, 227.
} 
individually and cumulated with the survivor pension (PBOAS), total and according to gender;

GDPtot $=$ total Gross Domestic Product in absolute terms, mil. Euro;

GDPcap $=$ Gross Domestic Product per capita, Euro;

$\mathrm{UR}=$ Unemployment Rate, \%;

$\mathrm{NE}=$ Net Earnings, Euro;

EDtert $=$ First stage of tertiary education, programmes that are theoretically based/research preparatory or giving access to professions with high skills requirements (level 5A).

Our developed model comprises, through its explanatory variables and accordingly to the literature, the determinants and shaping factors of the pension systems as post-employment benefits. Thus, within our empirical analysis, we focus on the country specific elements, by assessing the push factors, and to a smaller extent on the pull factors shaping pension levels and the number of pension beneficiaries. Nevertheless, our performed analyses take into consideration the particularities and characteristics of the economic activity, economic growth and the level of economic development and macroeconomic stability for considered panel countries, as well as the labor market elements (unemployment, earnings), respectively the educational background.

\subsection{Variables and indicators used for the empirical analysis}

The general set of indicators used for the empirical research of shaping factors of post-employment benefits as pension systems, as well as pension impacts on Serbian and Romanian economies (especially on productivity, labor market and poverty for pensioners) comprises:

i) pension specific indicators: the number of pension beneficiaries at $31^{\text {st }}$ December during 2005-2013; the number of pensioners on overall pension schemes - total and according to gender (females and males); the number of oldage pensioner - total and according to gender (females and males); cumulated number of old-age and survivor pension beneficiaries; pension values; expenses on pension funds as percentage of GDP;

ii) macroeconomic and labor market indicators: total (mil. Euro) and per capita (Euro) gross domestic product; resource productivity (Euro per kg); at-riskof-poverty rate for pensioners; employment and unemployment rates (\%); net earnings (Euro), tertiary education level.

We used national data sources for pension and labor market specific indicators covering the 2005-2013 period, respectively the Eurostat Database of the European Commission for macroeconomic and productivity indicators. 
All developed models and data were processed through Stata 12 econometric package.

\section{Results and discussions}

The empirical analysis conducted for the assessment of pension systems in Romania and Serbia has a double objective: (i) first, to highlight the shaping factors of the pension systems for the two countries considered and (ii) second, to evaluate the impact of pension schemes on the economic activity, productivity, and labor market. The main research limit for the performed empirical analysis is the lack of proper data detailed on long time series regarding the pension indicators, mainly for Serbia. Thus, in order to complete the database and provide accurate results for our developed models, we proceeded to interpolation and extrapolation in the early phase of the research for Serbian pension indicators.

\subsection{Shaping factors of pension systems in Romania and Serbia}

In order to identify and assess the shaping factors of pension systems in Romania and Serbia we developed a complex set of double-log macroeconometric models, based on various macroeconomic and pension specific indicators. The models were processed based on random and fixed effects through least squares method, respectively OLS (Ordinary Least Squares) for the fixed effects models (FE - Fixed Effects Models) and GLS (Generalized Least Squares) in the case of random effects models ( $R E$ - Random Effects Models). Moreover, we used the MLE - Maximum Likelihood Estimator to consolidate and verify the accuracy of estimated coefficients through a different method and we processed all developed models using robust standard errors. The results are synthesized and presented in appendix 1 .

Taking all these into consideration and based on the literature review we developed four sets of double-log models based on random effects and maximum likelihood estimations. The first set of econometric models focuses on total gross domestic product in absolute terms (GDPtot), along with other indicators, respectively unemployment (UR), net earnings (NE) and the educational level (EDtert), while the second set is centered on the use of per capita GDP (GDPcap) along with the same labor market indicators in different combination.

As regarding the use of pension specific indicators, we took into account the number of old-age pension beneficiaries (PBOA), individually and cumulated with the survivor pension (PBOAS), total and according to gender.

The results obtained after processing these models based on GLS for random effects and maximum likelihood estimations are almost similar regarding the coefficients, slightly differences being registered only in the case of standard 
errors of parameters associated with every model. Thus, we can observe that the level of statistical significance for the coefficients estimated through least squares (GLS) and maximum likelihood (MLE) methods is very high, mostly at $0.1 \%$. At the same time, if we analyze the values of Wald tests for multiple regression models (especially model 5 and model 7 ), we can point out that all explanatory variables have a significant joint influence on pension specific indicators as dependent variables, these results being extremely important for correct specification of the model. Nevertheless, we used the correlation matrix and Stata algorithms for the multicollinearity hypothesis and Breusch Pagan test for homoscedasticity, the results being thus valid.

Through the perspective of the results obtained we can highlight the importance of economic activity in shaping pension systems in Romania and Serbia, the empirical analysis suggesting that there is evidence to attest that a $1 \%$ increase in the level of total GDP could lead to a $0.918 \%$ increase in the number of old-age pension beneficiaries, while the similar improve in per capita GDP could induce a significant increase in the number of old-age pensioners by $1.933 \%$.

Moreover, an increase in unemployment rates may induce a perception of uncertainty for a specific job or the impossibility of finding one at an advanced age, these elements could then lead to an early retirement decision, thus increasing the number of old-age pensioners (with about $0.5 \%$ ). At the same time, an improvement in the level of net earnings represents a significant incentive to remain active within the labor market, thus reducing the total number of pension beneficiaries, as well as the old-age pensioners with about $1.5 \%$, according to the results presented in appendix 1. Still, the per capita income increase implies an improvement of living standards and the assurance of financial resources vital for after-retirement period, thus leading to an increase in the total number and old-age pensioners.

\subsection{The impact of pensions as post-employment benefits on economic growth and the labor market}

In order to assess the impact of pension systems on Romanian and Serbian economies, by following the economic literature and specific methodology, we developed a set of eight models processed based on fixed effects (FE) and random effects (RE) through least squares method (Ordinary Least Squares - OLS for FE models and Generalized Least Squares - GLS for RE models). The models are based on two fundamental pension indicators, respectively the total number of old age pension beneficiaries and the cumulated number of old-age with survivor pensioners. The results obtained are synthesized and presented in appendix 2.

Thus, we analyzed the pension impact on resource productivity (model 1), on net earnings (model 2), on the labor market through unemployment rate (model 3) and employment rate (model 4), as well as on the overall economic activity and 
living standards through at-risk-of-poverty rate for pensioners (model 5), total (model 6) and per capita (model 7) GDP, respectively on tertiary education level (model 8).

In order to validate the models following OLS (Ordinary Least Squares) and GLS (Generalized Least Squares) basic hypotheses for BLUE (Best Linear Unbiased) estimators, we performed the correlation matrix and take use of Stata algorithms for the multicollinearity hypothesis, as well as the Breusch Pagan test for homoscedasticity, and Wooldridge test for serial correlation, the results being thus valid. Nevertheless, the Hausman test applied in order to differentiate the fixed from random effects estimates validated the results of random effects models.

The accuracy of estimated coefficients is also validated through the high level of statistical significance, mostly at $0.1 \%$, as well as through the level of $\mathrm{R}$-square and its adjusted values, Fisher and Wald tests. Thus, especially in the case of model 6,7 and 8 which comprise the overall economic activity, the R-squared values highlight that more than $50 \%$ (about $90 \%$ in the case of model 6 - total GDP) in the variation of old-age pensioners, both individually and cumulated with the survivor pension beneficiaries could be explained by the selected explanatory variables.

Our results comply with the economic literature highlighting that postemployment benefits such as pensions can lead to an increase in productivity, earnings and improve the living standards, as well as the educational level. Thus, there is evidence to attest that an increase in the number of old-age pensioners for the two countries considered can lead to a $0.088 \%$ increase in productivity and a $0.351 \%$ increase in the level of net earnings. The positive effects of such a measure are also reflected in a total GDP increase by $1.041 \%$ and a per capita GDP increase by $0.275 \%$, reducing at the same time the at-risk-of-poverty rate for pensioners by $0.265 \%$. Moreover, a $1 \%$ increase in the old-age number of pensioners (a quantitative perspective) generates positive labor market impacts mainly through a significant reduction in unemployment rates by $0.573 \%$ and a slight increase in employment rates by $0.082 \%$.

The positive impact is also revealed by an improvement in educational levels, the increase in the number of old-age pensioners leading to a significant increase in the number of persons finishing the first stage of tertiary education, respectively those programmes that are theoretically based/research preparatory or giving access to professions with high skills requirements.

Similar tendencies and impacts can be observed if we take into account the number of survivor pensioners. 


\section{Concluding remarks}

The comparative analysis of employee benefits granted by various entities in Romania and Serbia highlights the importance given during the past few years to post-employment benefits, especially retirement advantages and pensions, locally and globally, as well as to the sustainability of the pension systems and to various measures that should be adopted and implemented to insure transparency and to facilitate a possible change in pension indexation methods.

The empirical research performed in order to assess the shaping factors and economic impacts of pension systems in Romania and Serbia complies with the major issues revealed by the literature and highlights that pensions can lead to positive economic effects, having a major impact on labor and resource productivity, labor market stability and general population welfare.

From the empirical perspective, our results point out that the main shaping factors of Serbian and Romanian pension systems are the level of total and per capita GDP, the labor market stability and the level of net earnings. Thus, there is a positive impact of the economic activity in shaping the pension systems for the two countries considered. An improvement in the living standards could lead to an increase in the number of pension beneficiaries due to a certain level of income for pensioners after their retirement. Nevertheless, labor market instabilities reflected mainly through a high level of unemployment could lead to an increase in the number of pensioners for Romania and Serbia.

The economic impact of pension schemes in Romania and Serbia is confirmed by the results and complies with the economic literature highlighting that post-employment benefits such as pensions granted by companies represent important incentives that increase employment, productivity and education, leading to economic growth. The results also point out that an increase in the number of old-age pensioners can reduce unemployment, having positive effects on total and per capita GDP, respectively on living standards through a significant reduction of the poverty rate for pensioners.

\section{Literature}

- Banerjee Dina, Perrucci Cummings Carolyn (2012): "Employee Benefits and Policies: Do They Make a Difference for Work/Family Conflict?”, Journal of Sociology \& Social Welfare, 39(3), 131-147.

- Baum F. Christopher (2001): An Introduction to Modern Econometrics Using Stata, Stata Press.

- Beju D. (2007): "Coordonate ale reformei sistemului de pensii: cazul României”, Transylvanian Review of Administrative Sciences, 20, 16-32. 
- Clark Robert, Morrill Melinda Sandler, Vanderweide David (2013): "Defined benefit pension plan distribution decisions by public sector employees", Journal of Public Economics, 1-16.

- Dorsey Stuart, Cornwell Christopher, Macpherson David (1998): "Pensions and the Labor Market", in Pensions and Productivity, Kalamazoo, MI: W.E. Upjohn Institute for Employment Research, 1-12.

- Lazear Edward (2000): "Performance Pay and Productivity", American Economic Review, American Economic Association, 90(5), 1346-1361.

- Mulvaney Michael (2011): „A Study of the Role of Family-Friendly Employee Benefits Programs, Job Attitudes, and Self-Efficacy among Public Park and Recreation Employees", Journal of Park and Recreation Administration, 29(1), 58-79.

- Simon Herbert (1991): “Organizations and Markets”, Journal of Economic Perspectives, American Economic Association, 5(2), 25-44.

- Society for Human Resource Management (SHRM): 2012 Employee benefits: A Research Report, The Employee Benefits Landscape in a Recovering Economy.

- International Accounting Standard 19 - IAS 19 - Employee Benefits.

- International Accounting Standard 26 - IAS 26 - Accounting and Reporting by Retirement Benefit Plans.

- National House of Public Pensions in Romania, Department of Projects, Studies and Analyses, Monthly Statistics, Pillar I.

- European Commission, Eurostat Database, EU LFS, National Accounts, Labor Market, Demography - Population.

- Statistical Office of the Republic of Serbia.

Paper received: May $22^{\text {nd }}, 2015$

Approved for publication: June $16^{\text {th }}, 2015$
Rad primljen: 22. maj 2015. Odobren za štampu: 16. jun 2015. 
Margareta Karan, student doktorskih studija

Fakultet za ekonomiju i poslovnu administraciju,

Zapadni univerzitet u Temišvaru, Rumunija

Dr Gratijela Đorđijana Noja

Fakultet za ekonomiju i poslovnu administraciju, Zapadni univerzitet u Temišvaru, Rumunija

\section{EMPIRIJSKA KOMPARATIVNA ANALIZA BENEFICIJA ZA ZAPOSLENE U MULTINACIONALNIM KOMPANIJAMA: PRIMERI RUMUNIJE I SRBIJE}

\section{S a ž e t a k}

Ovaj rad ima za cilj da analizira beneficije koje zaposlenima posle prestanka radnog odnosa obezbeđuju multinacionalne kompanije, s akcentom na pogodnostima za penzionisanje i penzioni sistem u Rumuniji i Srbiji. Ekonomska literatura ističe bitnu ulogu programa penzionisanja u osiguranju odgovarajućeg nivoa dohotka posle penzionisanja, u cilju smanjivanja siromaštva i povećanja produktivnosti, sa značajnim pozitivnim efektima na sveukupnoj ekonomskoj aktivnosti. Naše istraživanje je zasnovano na razvoju nekoliko dvostrukih logaritamskih modela sa fiksnim i slučajnim efektima kao i dinamičkog modela sa raspoređenim vremenskim pomakom, koristeći panel strukturu za period 2005-2013. i kompleksan set indikatora (nacionalni računi - BDP ukupno i po stanovniku; tržište rada - zaposlenost, nezaposlenost, produktivnost, zarade; srednje i visoko obrazovanje; specifični podaci za penzije - opšti korisnici, starosne penzije i minimalne penzije, ukupno i po polu, kao i troškovi za penzije kao procenat BDP). Rezultati pokazuju da penzije predstavljaju podstrek za zaposlene utičući na porast produktivnosti rada. Istovremeno, starosne penzije pozitivno utiču na privredni rast i zaposlenost u obe ispitivane zemlje, značajno smanjujući stopu siromaštva penzionera. Ipak, oba penziona sistema su modelirana prema ekonomskoj aktivnosti, obrazovanju zaposlenih kao i prema nivou neto zarada.

Ključne reči: beneficije za zaposlene, privredni rast, zarade, penzioni sistem, produktivnost 